further excursion to the south-east to a savanna region, situated in a depression among the mountains, and called by the natives "Valle Nuevo." The path led over forest-clad mountains with intervening gorges, and formed a continual ascent till the Valle Nuevo was reached, which is 7450 feet above the sea. One of the forest tracts which the traveller lraversed was especially dense and almost impassable ; beautiful mosses, ferns, orchids, lycopods, and other epiphytes were growing on the trees. The Valle Nuevo is surrounded by low hills, which form the culminating points of the range; the highest of these, viz. Pico del Valle Nuevo ( 8630 feet above the sea-level) was ascended by the traveller.

DR. Rink contributes to the current number of Prtermann's Mitteilungen an accuunt of the results of the recent journeys made by Lieuts. Ryder and Block along the coast of Green land to the north of Upernivik in 1887 . By accurate measurements made in the ice-fiords of Angpadlar Fok, \&c., both in April and August, some interesting and important results have been secured as regards the physical geography of this region. Some of the ice-fiords are very prolific in ice-bergs, notably that of Giesecke, where the edge of the permanent ice has retreated considerably within recent years. The results show not only the extraordinary rapidity, but the great variableness in the movements of the ice, apart apparently from the temperature of the time of year. The average temperature of the air during the measurements from A pril 20 to 24 , was from $-9^{\circ} \mathrm{F}$, to $-15^{\circ}$. On January 28 the water temperature, at a point where the icefiord was 512 fathoms in depth, was as follows: at the surface $27^{\circ} \cdot 7 \mathrm{~F}$, at 50 fathoms $28^{\circ} .9$, at 200 fathoms $32^{\circ}$, and at 287 fathoms $32^{\circ} \cdot 2$. The question of the limit and movements of the inland ice of Greenland, to which the attention of recent Danish explorations has been directel, and towards the solution of which the results obtained by Lieuts. Ryder and Block have materially contributed, is discussed by Herr Rink in his paper, which also gives some interesting notes on the botany, geology, and ethnography of the country.

In the April number of the Proceedings of the Royal Geographical Society there is an excellent new map of Siam, based on the surveys of Mr. James McCarthy. There also will be found the second and third of General Strachey's Cambridge geographical lectures.

AT the last meeting of the Royal Geographical Society a paper of unusual interest and originality, on the Solomon Islands, was read by Mr. C. M. Woodford, who spent several months in the group in 1886-87. Mr. Woodford's attention was mainly directed to Treasury Island, his head-quarters for some months being at $\mathrm{Alu}$, on that island. $\mathrm{He}$ made many journeys into the interior, and was so successful that he obtained nearly 17,000 specimens in natural history, which, so far as they have been examined, have been found to conprise three ne:v genera, and eight new species of mammals, fifteen new species of birds, six new species of reptiles, and over a hundred new species of Lepidoptera. Mr. Woodford visited, besides Treasury Island, the islands of Fauro, New Georgia, Guadalcanar, and others, exploring their interiors as far as possible, and in the case of Guadalcanar attempting to ascend Mount Lamn a : 8000 feet), without, however, succeeding. He followed the Bokokembo River as far as possible, finding the vegetation most luxuriant, and composed of large Ficus and other forest trees, with o:casional clumps of sago and areca palms, but few coco-nuts. The const natives are greatly afraid to venture into the interior, partly through fe.sr of the bush-folk who live in the mountains, and partly through superstition. Mr. Woodford's observations on the natives are of great value; he had unusual opportunities of observing their modes of life. They are mostly inveterate head-hunters and cannibals. Natives of different parts of the group differ considerably from one another, but they belong to the Melanesian or Papuan type. Mr. Woodford believes, however, that on the island of Ysabel there is a strong infusion of Polynesian blood from Ongtong Java, or Lord Howe's Group, as canses are known to have been driven in bad weather from that group, and to have arriver on the ccast of Ysabel. The natives of Bouka and Bougainville, and of the islands of Bougainville Straits and of Choiseul, are intensely black in colour, but as one journeys eastward the colour changes to a dark brown. They have woolly hair, but occasionally natives are met with wavy, and in some cases straight hair. Mr. Woodford attributes this fact to an infusion of Polynesian blood, and has noticed it in natives from Ysabel, also at Fauro.
THE Royal Geographical Society of Sweden has awarded the Vega Gold Medal-instituted in honour of Nordenskiöld's voyage - to Dr. Wilhelm Junker, the celebrated African traveller. The medal, which has not been awarded since 1884 , has hitherto had only four recipients, viz. Nordenskiöld, Palander, Prejevalsky, and Stanley.

\section{THE ATOLL OF DIEGO GARCIA AND THE CORAL FORMATIONS OF THE INDIAN OCEAN.}

DIEGO GARCIA is a typical atoll; a narrow strip of land varying in width from a mile to 30 yards, nearly completely encircles a lagoon of irregular shape. The lagoon is open to the ocean towards the north-west, its mouth being divided by three small islets into four channels, of which three are sufficiently deep to allow ships to enter the lagoon. The whole of the land composing the atoll is very low; the highest point in the island is not more than 30 feet above the level of high tide, and this height, which is quite exceptional, is due to the accumulation of great heaps of sand through the action of the south-east trade winds which blow with considerable strength for more than one-half of the year. Diego Garcia is the southernmost atoll of the Chagos Group ; it lies in S. lat. $7^{\circ} 26^{\prime}$, E. long. $72^{\circ} 23^{\prime}$, and forms the last of the great chain of cural formations reaching from the Laccadive Islands, through the Maldives to the Chagos Group. To i's south-west lie the submerged atoll-shaped reefs known as Pitt's Bank and Centurion's Bank, to its north lies the huge submerged atoll known as the Great Chagos Bank. It is an intercsting fact that throughout the Laccadive, Maldive, and Chagos Groaps there is no instance of a fringing or of a barrier reef; nothing but coral structure rises above the waves; all the islands are atolls; none of these are upraised, but there are several sub. merged banks. The existence of this long line of atolls seemed to be one of the strongest arguments in favour of Darwin's theory of the formation of coral reefs.

In Diego Garcia the nature of the soil varies considerably from place to place. In sume localities it consists of nothing else than bare coral rock upon the surface of which coral boulders are scattcred about ; in other places it is composed wholly of calcareous sand, and one may dig down for 6 or 8 feet without finding coral rock. It is obvious after a short examination that some part; of the land are older than others, and that the great strip of land was formerly a series of disconnected islets which have since been joined together by the accumulation of sand and coral débris between them. In the older parts of the island, which have apparently been covered with vegetation for a considerable period, a thick peaty mould has been formed by the decay of fallen leaves and stems of trees and shrubs.

Throughout the island the outer or seaward shore is higher than the inner or lagoonward shore, owing to the pile of coral boulders thrown up in the form of a low rampart along the former by the action of the waves. In most places a flat reef extends fully 60 yards seaward of the rampart; and this reef is just uncovered at low spring tides. As a rule the inner shore slopes gently down into the lagoon for some distance, and then pitches down rather suddenly to a depth of ro or I2 fathoms, but in some places there is a depth of 6 or 8 fathoms close up to the inner shores. Marshy pools of fresh or brackish water are found in the centre of the strip of land on the south-east and west sides of the island ; into these the sea enters in many cases during the highest spring tides, and at the south-east and south ends of the island it has established permanent breaches into some of these pools, through which the tide runs in and out regularly from the lagoon. Thus there are formed sheets of water like secondary lagoons within the strip of land; these are known on the island by the name of barachois, and they are of some importance when one comes to consider the amount of change which is continually going on in the island.

Externally the shores slope away very rapidly to considerable depths, the sounding-line giving depths of 250 fathoms and upwards at a distance of a few hundred yards from the edge of the reef, excepting at Horsburgh Point at the south-east side, where a depth of 45 fathoms is found at a distance of $\mathrm{I}$ mile from the shore. After a stay of two or three months on the island one cannot fail to be impressed with the immense amount of

${ }^{x}$ By G. C. Bourne, B A., F.L S., Fellow of New College and Assistant to the Linacre Professor in the Un versity of Oxford. Communicated to the Royal Society by Prof. E. Ray Lankester, F.R.S. 
change which is continually in progress. Large masses of sand are in the space of a month deposited in one spot to be swept away during the next month and deposited in another. Everywhere there is evidence that the sea has encroached upon the land, or that the land has in its turn gained upon the sea. In one place numerous dead and fallen cocoa-nut palms show where old-established land has been carried away; in an adjoining spot tracts of sand, either bare or covered with a scanty growth of young shrubs, show where the combined action of wind and waves has added a new piece to the island. Within the lagoon the currents are constantly changing in force and direction, and their every change affects the growth of coral in their track. In estimating the structure of the atoll these changes should be kept in mind, although their complexity makes it far more difficult to arrive at a correct conclusion.

In the course of my investigations I learnt to distinguish the following linds of coral rock formed by the action of the waves or wind, or both combined.

Firstly, recf rock, a tolerably homogeneous mass of compacted coral debris, the component parts of which are so thoroughly infiltrated with carbonate of lime held in solution in the sea-water that-the masses of fragments of coral composing the rock are rarely distinguished from one another. This form of rock exhibits a fine horizontal stratification; it is invariably formed under the sea or between tide marks.

Secondly, boulder rock, formed just above high-tide mark by means of the masses of coral which are transported across the reefs by the waves and are piled up to form the low rampart already alluded to. The interstices of the boulders are soon filled up with coral déoris and sand, and are cemented together by the spray. Such rock is only formed on the seaward shores, and invariably shows a stratification dipping downwards towards the sea.

Thirdly, shingle rock, which may be of two kinds. The first kind is horizontally stratified, and is scarcely distinguishable from reef rock, except in its finer texture; it is formed below water or between tide marks by the agglomeration of small pieces of broken coral, among which are included numerous shells of mollusks, remains of Crustacea, Echinoderms, \&c., and in the more sheltered parts of the lagoon it may include considerable masses of dead Madrepores embedded in their natural position in the rock. This rock is of a looser texture than the reef rock. The second kind of shingle rock is formed above high-water mark by the action of the waves. It is entirely composed of small fragments, and exhibits a fine stratification dipping seawards at an angle.

Lastly, there is the sand rock, formed above water by the action of the wind. Wherever masses of fine sand are piled up within reach of the spray they are gradually compacted, and form a friable rock, the stratification of which dips seaward.

In many parts of the island I observed that the land was composed of stratified reef or shingle rock, the strata of which were perfectly borizontal, and did not dip down towards either shore. Having observed the manner in which the different kinds of coral rock were formed, I was at a loss to understand how such horizontally stratified masses could have been formed in their present position above high-water mark, and could only believe that they were originally formed as reef or shingle rock below high-water mark, and had been subsequently raised to their present position. I was thus led to believe that a slight elevation had taken place, and this belicf was strengthened by a study of the formation of East. Islet. This islet is about 800 yards long, and nearly 10o yards broad; its westermost extremity is composed of masses of sand piled up on the underlying reef rock, and in this place there is a clump of high trees (Hernandia peltata). The eastern and by far the larger part of the islet is of different formation. The even surface of the soil is covered with a low scrub, but bears no trees nor cocoa-nut palms. It forms a low platean, the surface of which does not slope down towards the lagoon, but is perfectly horizontal, and stands 4 feet above the very highest spring tides. The shore on the lagoonward side shows an abrupt fall of 6 feet to the reef, which in this place extends for a distance of 50 yards towards the lagoon, and is only left uncovered at the lowest spring tides. At the eastern extremity of the island there is no reef, but from $I \frac{1}{2}$ to 2 fathoms of water are found within a few yards of the shore. This point is exposed to the ocean, and a strong and constant current sets against it, so that it is undergoing a considerable amount of erosion. On the north or seaward side the reef again extends outwards from the shore, the latter differing from the inner shore in the presence of a talus of large boulders which have been thrown up against it by the waves. Wells have been sunk in numerous parts of the island, though, for some reason which I cannot explain, water is only found in one of them. Numerous pits, some of which are 9 feet deep, have also been dug for the purpose of planting cocoanuts. These pits and wells expose the interesting structure of the superficial part of the island. Beneath a thin surface layer of sand and mould lies a horizontal layer of stratified shingle rock, in which large embedded coral masses may occasionally be distinguished; this layer is about $2 \frac{1}{2}$ feet thick. Beneath is a layer of loose coral sand about 18 inches thick, and beneath that is another layer of coral rock of the same character as the first, and about 3 feet thick. Beneath this is another layer of friable sand lying on the solid reef rock into which the excavations did not penetrate. These layers lie perfectly horizontally, and do not dip in any direction. They crop out above the reef on the steep eastern and southern shores, and as the loose sand is washed out by the waves the overhanging layer of rock breaks off and falls down in large masses. The central parts of this area are absolutely beyond the reach of any waves at the present time, and as the strata of rock and sand run evenly through it there is no evidence of its having been formed by successive additions of material through the action of the waves. Nor can it possibly have been formed under the surface of the water unless it has since been raised to its present position, for, as I have said, its upper surface is 4 feet above the level of high spring tidles. On one occasion when the tide rose to an abnormal height and invaded several parts of the main island, I saw that the water reached to within 3 feet of the top of the shore, but even then the whole of the upper stratum of coral rock was well above the waves. It is scarcely credible that an even layer of shingle rock could have been formed above the highest high-water mark.

My belief in elevation is further strengthened by the following facts, communicated to me by M. Spurs, a resident for twenty-five years at Diego, an ardent naturalist, and much interested in coral formations.

A small shore crab of the genus Ocypus is always to be found on the sandy flats between high and low water marks. These crabs, as is well known, form numerous galleries in the fine muddy sand, which they line with seaweed, \&c., to prevent their falling in. These galleries open to the surface by short passages placed perpendicularly, the mouths of which open only a few inches above the level of low tide. This crab is only found on the shore between tide marks; on the dry land its place is taken by Gearcinus, another genus of crab, which forms different burrows. In the west part of East Islet there is an aggregate of friable, scarcely compacted sand, which has somewhat the appearance of half-dried clay. It lies 5 feet above high-water mark, and was found by M. Spurs, during some excavations which he had to make for the purpose of constructing a slip for boats, to be riddled with the seaweed-lined galleries of Ocypus, evidently long since disused and empty.

Having made this observation on East Island, M. Spurs made a search in similar formatiors on the main island, and found, he tells me, precisely the same facts in several instances, aggregates of sand lying at some distance above high-water mark, riddled with the abandoned burrows of Ocypus. Now, since the burrows of Ocypus are quite characteristic, and could not have been mistaken by so sood an observer as M. Spurs for those of another species, and since they are in the present day only found between tide marks, these observations afford a further presumption in favour of a slight elevation having recently taken place. In any case they preclude the idea of any subsidence being in progress, as $\mathrm{Mr}$. Darwin fancied to be the case in the Keeling atoll. M. Spurs further informs me that, during the time that he was superintendent of the oil company's estate, he caused more than 30,000 pits to be dug on the main island for the purpose of planting cocoa-nut palms, and that he frequently observed in different localities the same alternate layers of sand and rock that I have described as existing on East Island. These alternations of sand and rock would suggest alternations of very slight subsidence with very slight elevation, rather than a single movement of upheaval, yet on the supposition that all the layers were formed beneath the water, as their horizontal stratification leads me to believe, I can venture on the following explanation. The mass of rock which forms the base upon which the islets and other dry land rests is solid reef rock, and the whole floor of the lagoon is similarly formed. 
The latter is covered at depths of 3 or 4 fathoms and upwards by a layer of fine sand, which may attain a thickness of 2 or 3 feet. In protected parts of the lagoon and in spots where the changeable currents have ceased to deposit any quantity of sand, corals will grow in considerable quantities, chiefly those wide-spreading ing species of Madrepora which cannot find a lodging on the exterior of the reef, where they would be dashed to pieces by the waves. By the continual growth of new colonies on the top of the old ones which have died, a layer of solid rock of considerable thickness may be formed. Whilst diving for corals at the lower part of the lagoon, I often noticed such layers of halfformed rock on which living coral was growing or not, according as the constantly changing currents were at that time throwing up sand in the locality or not. Thus on the west side of the lagoon, off Point Marianne, there are large tracts of recently formed coral rock, on which no living corals are to be seen, whilst on the east side of the lagoon, exactly opposite to Point Marianne, a similar basis of rock is luxuriantly covered with growing coral.

Now, as the currents are constantly changing, and as the changes may, as I saw, affect an area some miles in extent, one may suppose that an area was first covered with corals growing on the sand, which everywhere covers the reef rock, when the latter lies more than a fathom below the surface. A change in the currents brought abundant sand to the spot, killed the corals, and deposited an even layer of sand of some little thickness over the rock formed by the skeletons of the dead corals. A firther change in the currents would again render the spot suitable for coral growth, and a new layer of rock would be formed over the last layer of sand. I have seen quite analogous formations in progress in a fathom of water a little way above Point Marianne. Raise the formation to the surface, and you get that stratification which occurs in so many parts of the island, a stratification which cannot be explained on any theory of subsidence, and is scarcely less difficult to explain on the supposition of rest. At first I had some hesitation in extending to an island on the borders of the lagoon, as is East Island, a view of the formation of Jayers of sand and rock derived from an inspection of the interior of the lagoon, but afterwards $I$ saw that similar layers were being formed just within the large reef known as Spur's Reef, west of Middle Island, so that no objection can be raised on that score. The whole character of the Chagos Group is very much opposed to the theory that atolls and barrier reefs are formed during subsidence. There are several atolls rising above the waves, that of Peros Banhos being 55 miles in circuit, and composed of numerous small islets placed upon a ring-shaped reef through which there are several large and deep channels, Egmont or Six Islands is an instance of an atoll in which the encircling reef is perfect and unbroken by any channels, the land consisting of six islets placed for the most part on the southern and western sides of the reef. There are several submerged banks, nearly all of which have an atoll form. Of these the best known is the Great Chagos Bank, a huge submerged atoll 95 miles long and 65 miles broad, having a depth of 4 to IO fathoms over a narrow rim around its periphery, and a central lagoon of a depth varying up to 45 fathoms. South-west of the Great Chagos Bank, distant less than 15 miles, lies the atoll of Six Is'ands, and on the other side of these, scarcely 12 miles distant, lies another submerged atoll, known as Pitt's Bank. South-west of Pitt's Bank are two smaller banks, Ganges and Centurion's Banks. Darwin considered that the Great Chagos Bank afforded particularly good evidence of the truth of the subsidence theory. He regarded it as an atoll carried down by a too rapid subsidence below the depth at which reef-building corals fourish. The same would be the case for Pitt's Bank and the two others just mentioned. A more intimate knowledge of the Great Chagos Bank, and of the relations of it and other submerged banks of existing land, shows this view to be untenable. In the first place, the rim of the Great Chagos Bank is on an average not more than 6 fathoms below the surface, and therefore situated in a depth eminently favourable for coral growth, and there are actually six islets on the northern and western edges rising above the water, and some of them inhabited. Secondly, any such rapid subsidence could not have affected areas only 30 miles apart without involving the Six Islands atoll lying directly between them. A similar argument might be extended to the more northern islands of the Chagos Group, and even to Diego Garcia itself, although it lies somewhat apart from the rest of the group. Again, if atolls and barrier reefs are formed around subsiding peaks, it is at least curious that throughout the Lacca- dive, Maldive, and Chagos Groups there are no instances of high islands surrounded by barrier reefs, marking the last remnants of pre-existing land. In the more western parts of the Indian Ocean, between Madagascar and the Seychelles, there are numerous atoll islands, and in long. $60^{\circ} \mathrm{E}$. there lie the submerged Saya de Malha Bank and the reef known as Cargadn Carajos. Between these two lies the extensive Nazareth Bank, having over it depths of from I 4 to 45 fathoms. The Saya de Malha Bank appears to have the characters of a submerged atoll, having a central depression of 65 fathoms, surrounded by a rim which has only 8 to 16 fathoms on its eastern side, but 22 fathoms on the western. Some of the groups north of Mada. gascar afford very good evidence of upheaval. Aldabra Island, situated in lat. $9^{\circ} \mathbf{2 2}^{\prime} \mathrm{S}$., long. $46^{\circ} 14^{\prime} \mathrm{E}$., is a perfect instance of an upraised atoll. Captain Wharton describes the external shores as consisting of low coral cliffs, about 20 feet high, the surface of the land being composed of jagged coral rock. The lagoon is entered by a passage varying from I I to 5 fathoms in depth, but its internal portions are either very shallow or partly dry at low water. Not far distant is the Cosmo Ledo Group, a perfect atoll, with a lagoon some 4 fathoms deep, or less. There are ten islets of various sizes on the reef, and all of them appear to have been elevated some ro feet. There are some hills 40 and 50 feet high on the two largest islands, but these appear, accord. ing to Captain Wharton, to be formed of blown sand. The Farquhar Group and Assumption Island, situated within the same area, have been raised, according to the same authority, some 10 feet. Providence Island, in lat. $9^{\circ} 14^{\prime} \mathrm{S}$., long. $51^{\circ} 2^{\prime}$ E., appears to be a low island situated upon the edge of the atoll-shaped Providence Reef. At a distance of 19 miles from Providence Island is the island of St. Pierre, which has no fringing reef. It is particularly interesting, for although it is in close proximity to the low Providence atoll, it has been raised about 40 feet above high water, and in the absence of a fringing reef the sea breaks with great violence against a low cliffy coast, hollowing out a number of caverns which, from the description given in the sailing directions for Mauritus and its islands, appear to open inshore by " blow-holes." "

Near and among these raised coral formations are several sub. merged banks, the most important of which is the McLeod Bank, situated in lat. $9^{\circ} 57^{\prime} \mathrm{S}$., long. $50^{\circ} 20^{\prime} \mathrm{E}$., between Providence Island and the Cosmo Ledo Group. The details show that there is a group of coral formations, situated in lat. $10^{\circ} \mathrm{S}$., north of Madagascar, in which are found raised atolls--atolls whose dry land just rises above the waves and submerged banks. There can be no clearer proof that atolls are formed in areas of elevation, and, if the facts which I have already stated concerning Diego Garcia are of any weight, it would seem that most of the coral formations of the Indian Ocean mark areas of elevation rather than of rest, certainly they are not evidence of subsidence.

Those who have felt that the evidence brought against Darwin's subsidence theory is too strong to be resisted, must often have felt that no satisfactory explanation of the lagoons of atolls or the lagoon channels of barrier reefs has been given in its place. Semper was the first to suggest that the lagoon was formed by a solution of the interior parts of the reef, and more recently this view has been urged with great force by Mirray, who points out, in addition, that corals on the periphery of a reef must, from their position, get the advantage over those more interiorly situated, being more directly in the track of food-bearing currents. Neither of these explanations has completely satisfied me. That sea-water exercises a solvent action upon carbonate of lime does not admit of doubt, and that the scour of tides, com. bined with this solvent action of the water, does affect the extent and depth of a lagoon is obvious. But I challenge the statement that the destructive agencies within an atoll or a submerged bank are in excess of the construction. It would be nearer the mark to say that they nearly balance one another. In the first place, the carbonate of lime held in solution by seawater is deposited as crystalline limestone in the interstices of dead corals or coral débris. Anyone who is acquainted with the structure of coralline rock knows how such a porous mass as a Mæandrina head becomes perfectly solid by the deposition of lime within its mass. This deposition can only be effected by the infiltration of sea-water. In reckoning the solvent action of sea-water, therefore, account must be taken of the fact that a not inconsiderable proportion of the carbonate of lime held in solution is redeposited in the form of crystalline limestone. Of

${ }^{x}$ For the information on the islands north of Madgascar I am indebted to the courtesy of Captain W. J. L. Wharton, R.N., F.R S. 
this, it seems, Mr. Murray has not taken sufficient account, and has, therefore, overstated the destructive agency of the sea. Secondly, the growth of corals, and the consequent formation of coral rock within the lagoon, is generally overlooked.

Whilst diving for corals at Diego Garcia, I had abundant opportunities of studying the formation of coral rock within the lagoon, in depths under 2 fathoms. The layers of tolerably compact rock thus formed are of no mean extent or thickness; they soon become covered with sand, and are thus protected from the solvent action of the water. I have found it impossible to reconcile Mr. Murray's views with what I saw of coral growth within a lagoon. Not only do the more delicate branching species of the Madreporaria flourish in considerable numbers, but true reef-building species-Porites, Mæandrina, Pocillopora, and various stout species of Madrepora-are found there. It is a mistake to suppose that certain species of corals are restricted to the external shores, others to the lagoon. My collections proved that many of the species growing in the lagoon at distances of 5 miles and upwards from its outlet are identical with those growing on the outer reef. In addition to them are numerous species, such as Seriatopora stricta, Mussa corynbosa, Favia lobata, Fungia dentata, and many others that are not found on the outside. The reason is that the last-named are either free forms, such as Fungia, or are attached by such slen. der and fragile stems to their supports that they could not possibly obtain a foothold and maintain themselves among the powerful currents and waves of the open ocean.

These various species, numbers of which grow close together, form knolls and patches within the lagoon, and it cannot be doubted that their tendency is to fill it up.

These considerations have led me to discredit the solution theory as an explanation of lagoons and lagoon channels, and other objections have been lately urged with great force by Captain Wharton. The conclusion which I reached, after carefully considering the conditions of submerged lakes of atoll form, is that the ring-shape of the outer reef is to be explained by the peculiarly favourable conditions for coral growth found on the external slopes. Although corals may, and do, flourish in lagoons, they are only found in knolls and patches, and are always liable to be smothered, when, by a change in the tidal currents, sand is thrown down upon the place where they are growing. On the external slopes, however, corals grow in extraordinary abundance, and chiefly those massive forms whose skeletons take so conspicuous a share in the formation of coral rock. If once it is admitted that the periphery of the reef offers peculiarly favourable conditions to the growth of reef-forming corals, it follows that, as the reef rises to the surface, its external parts will outstrip the more internal, and will reach the surface first, forming a rim around a central depression or lagoon. This elevated ring will be as marked a feature in submerged as in complete atolls.

Corals are always thickest along the slopes around a coral reef, and the reef tends to increase at its periphery, growing upwards there, whilst it tends at the same time to spread outwards. These principles hold good in the case of a submerged bank as well as in the case of a reef that is awash, and a submerged bank must tend in the course of time to reach the surface in its circum. ferential portions, and form an atoll-shaped reef, on the rim of which detritus may be heaped from place to place, forming shingle cays or islets which may temporarily form dry land. In atolls where storms are of frequent occurrence, regular stormbeaches may be formed, till the fragments piled high upon one another may form low islets standing some 6 or ro feet above high-water mark, upon which vegetation may subsequently find a footing. Atolls are often formed in this way, without any elevation taking place, and such has undoubtedly been the case in the Florida reefs, where atolls (the Tortugas) and barrier reefs and islands have been formed in an area of complete rest. No one who has read the admirable work of Alex. Agassiz on the Florida reefs can fail to agree with the author's conclusion that the islets there have been formed by the action of the wind and waves alone, without any assistance from the upheaval of the bed of the sea. But I am not satisfied that this has been the case in the Chagos Group. Storms are of very infrequent occurrence there, and the horizontal masses of reef rock standing above highwater mark cannot be attributed to the normal action of the prevailing winds and currents.

In the Florida reefs the nature of the soil betrays its originits strata slope towards the sea on every side, and the lamination of the rocks attests the long-continued action of waves and spray. But the alternate horizontal layers of sand and rock occurring so abundantly at Diego Garcia are quite different; they do not dip seawards, their composition differs from the rocks of the Florida reefs, and their edges, instead of showing signs of accumulation of fresh material, are often bluff, and show that the sea is gradually eating them away. It is difficult to explain these appearances except on the hypothesis of slight elevation. It might be objected that if any upheaval had taken place, the banks lying at various depths below the surface would have been raised to different heights, and that it would be in the highest degree unlikely that so many would be raised some 4 or 5 feet above high-water mark and no more, throughout so large areas as the Laccadive, Maldive, and Chagos Islands, and the various low groups in the Pacific. The force of the objection must be admitted, but it may be observed that atolls raised from Io to 40 feet above the waves are not so uncommon as has been hitherto supposed, and that the numerous submerged banks lying at very various depths show that all the reefs have not been raised to one height in a single area of elevation. The uniform level of many atolls and barrier reefs admits of a further explanation. A reef raised some few feet above the sea-level is at once attacked by the waves, and as the rim is very narrow, it must soon be worn away till the whole of the land is eaten away, and its surface is brought awash once more. Thus every slight movement of elevation would soon be compensated by the denuding action of the waves. The island of St. Pierre, already described, is a good instance of this process of erosion. It cannot be doubted that this island, which has recently been raised 40 feet, is undergoing rapid waste, and must soon be reduced to the level of the sea. At Diego Garcia I was astonished at the rapid destruction of dry land which is in progress, on the outside as well as the inside of the lagoon. The destruction is not so great on the outside as on the inside as a rule, for in the former case the rampart of coral boulders thrown up by the waves compensates in many places for their erosive action. But in the bay above Horsburgh Point, exposed to the full strength of the south-east trades, the destruction is very great. M. Spurs, an old resident of the island, writes to me on this subject: "Cette destruction est très rapide ; Diego perd en moyenne un pied de terrain par an, tant intérieurement qu'extérieurement, excepté aux pointes nord-est et nord-ouest, où une partie des sables, entrainés du fond de la baie par les vents de sud-est, conservent à ces deux pointes leur largeur première."

M. Spurs has over-estimated the rate of destruction, but there can be no doubt that it is very considerable. It is most conspicuous along the shores bordering the lagoon. The stumps of cscoa-nut palms, the newly-made breaches into the land, forming shallow inland lagoons, the vertical faces of old banks of halfconsolidated sand, all attest it. Just above Point Marianne is a road running along the lagoonward shore, which when $\mathrm{I}$ left the island had been narrowed by the action of the sea to a mere path, and was in some places almost impassable, as the sea had made clean breaches across it, and found its way into some shallow fresh-water lagoons lying on the other side of the road. I was assured that this road had been over 12 feet wide some years previously, and that it was formerly separated from the lagoon by a narrow strip of land of an equal width. Perhaps the best evidence of the destruction of land is afforded by the "barachois" at the southern extremity of the island. These barachois are inland lagoons connected with the main lagoon by a narrow outlet some 2 fathoms deep or more. They are filled and emptied every tide, and their floor is intersected by numerous small channels running in every direction. No corals grow within the barachois, and a slight study convinces the observer that the daily scour of the tides is denuding their shores and floors very considerably.

Barachois are formed in the following way :-During unusually high tides, when the waters of the lagoon are dammed back by a north-westerly wind of unusual violence, the water rises to great heights and invades the land in several places. In some instances it actually makes a breach in the lagoonward shore, and fills up the shallow depressions which are often found in the middle of the strip of land. A pool of salt water is thus formed, which kills the cocoa palms and other vegetation growing in its bed, and, as this process is repeated again and again, in the course of a few years a channel is cut out between the pool and the lagoon, which finally becomes so deep that spring tides, and finally even neap tides, run in and out of the pool regularly. As soon as these conditions are established, the channel is scoured out and deepened, and the daily tides scour out the bed of the pool, forming a complete barachois.

It is not easy for one who has not seen it to understand how 
much of the loose soil of a coral islet can be moved by a single tidal encroachment. It happened that I was riding past the very thin strip of land between Minni Minny and Barton Point the day after an abnormally high tide. The strip of land here is not more than 30 yards across, and the sea had washed right over it on the previous day, clearing away an amount of soil which was almost incredible. My companion, M. Casimir Leconte, told me that the sea had not been known to wash over this place before. It was apparent that, after a few more of such high tides as I had witnessed, a permanent breach would be made at this spot, and another lagoon outlet would be formed, which would be continually deepened as the tide set through it. At the south-eastern side of the island I noticed that the land was being rapidly destroyed on the outer shores just opposite to a half-formed barachois, whose margins are situated not 60 yards from the outer shore. If the same process of external destruction continues, whilst the barachois is deepened and scooped out from within, it will not be many years before the ocean makes a new channel into the lagoon at this point. Thus the continuous strip of land which now nearly encircles the lagoon of Diego Garcia is tending to be split up again into a series of islets. At the points where the breaches are made the tides and ocean currents will rush with great force into the lagoon, and will scour out deep channels similar to that now existing between Middle and East Islets.

These facts taken together show how the normal action of tides, winds, and waves is constantly tending to lower to the sealevel any dry land that may have been formed by elevation or otherwise. It does not seem to me to be surprising that the majority of atolls and barrier reefs are, under such circumstances, only just able to maintain their surfaces above the sea-level.

No explanation of atoll formation would be complete if it did not include an explanation of the Malclive atolls. This has been felt by Darwin, who has explained the formation according to his theory. Without attempting to enter into a lengthy discus. sion, I will give my own explanation of the atoll. Tilla douMatte atoll is, as is well known, a huge atoll composed of atolls. The islets forming the rim of the main atoll are themselves atolls with their own lagoons; the main lagoon contains a few secondary atolls corresponding to the coral patches in an ordinary atoll. It will be generally admitted that coral reefs are constantly increasing to seaward because of the excessive growth of coral on their external slopes. As the inward shores of an atoll are constantly being removed, and an atoll if completely formed tends to be broken up again into small islets when it has reached a certain size, and as the channels between the islets must be continually deepened by the scour of the tides until deep passages are formed, an atoll like Diego Garcia may be expected to reach in time a condition like that of Peros Banhos. It is probable that a large bank like the Great Chagos Bank, when it reaches the surface, can never give rise to a continuous strip of land, but must consist of a chain of islets separated by channels of some depth and by tracts of submerged reefs. The islets and tracts of reef in either case would be bounded by deeper channels, and these channels, swept by strong currents, would become wider and deeper, for corals could not thrive in them. After a time the islets would become so far isolated, and the entries into the lagoon would become so large and numerous, that oceanic conditions would prevail in the lagoon, and then there would be around each separate islet or piece of reef all the necessary conditions for the formation of a new atoll. The currents would impinge upon one side of the islet or reef, sweep round it, and give a backwash at the further side; the corals would flourish in the circumferential parts of the reef surrounding the islet, and new atolls with shallow lagoons would be formed.

In Tilla-dou-Matte the lagoons of the secondary atolls are tolerably deep. In this case they must have been formed before any land reached the surface. Applying the same reasoning as in the former case, it can readily be understood how in the case of the Great Chagos Bank, which has wide and deep breaches in many places, the isolated reefs as they grow to the surface must tend to assume an atoll form. An examination of the chart shows that this is the case. The Great Chagos Bank in the course

I This statement may at first sight seem at variance with what I have just said about the rapid destruction of land on the outer and inner shores of an atoll : but in the latter case it is land aboure water that is destroyed. Coin. cidently with this prose the reef rock below water is constantly to raise itself and to spread in all directions of corals and the accurulation of their skeletons of time will rise to the surface as an atoll composed of secondary atolls or atollons, similar to, but on a smaller scale than, the Tilla-dou-Matte atoll. The explanation of atollons in the centre of a large lagoon in which oceanic conditions have been established, is quite obvious.

\section{THE ROYAL HORTICULTURAL SOCIETY.}

N Tuesday, March 27, the Scientific Committee of the Royal Horticultural Society met in the Committee-room of the Drill Hall. Among the numerous subjects brought forward were the following:-

Dispersal of the Sced in Pinus insignis.-Dr. Masters, alluding to the great differences that exist in the species of Pinus, as to the time at which the constituent scales of the cone separate in order to liberate the seed, showed a series of cones of Pinus insignis, the oldest of which bore the date 1864. In this all the scales were widely separate. The most recent cones dated from 1877 , and in them the scales were not at all separated. Between these two extremes, cones were shown exhibiting almost every intermediate stage of separation. It is to be remarked that the separation begins generally just above the centre of the pendulous cone on the side furthest away from the branch, at the place where the excentricity of the cone, clue to the free exposure to light and air, and the absence of obstacles afforded by the branch was greatest, and that it follows a spiral course towards the base of the cone. The scales separate in successive spiral coils, till, at length, all except a few at the base and apex respectively, and which are probably sterile, are separated one from the other.

Semi-double and other Orchids.-Dr. Masters explained the construction of numerous malformed orchids which were interesting as throwing light on the morphology of the order. Some extraordinary malformations of Fuchsias were shown, and a drawing was exhibited of a magnificent new Anthurium, which had appeared accidentally with an importation of Cattleya Gaskelliana, in the garden of the Right Hon. J. Chamberlain. The heart-shaped leaves are of gigantic size, and the large boatshaped spathe is of the richest crimson colour.

Eucalyptus urnigcra.-Dr. Masters showed specinens of this Tasmanian species in flower and fruit. They had been received from Whittinghame Gardens, Prestonkirk, near Edinburgh, not far from the sea, and where the tree is perfectly hardy.

Daffodil with Crested Corona.-Rev. E. C. Gabbett sent through Dr. Masters two flowers of a curious Daffodil from plants growing on his lawn in Co. Limerick. The "frill," or outgrowth, is produced from the outer surface of the corona, which has thus a very peculiar appearance.

Douglasia lavigata.-Mr. G. F. Wilson alluded to this plant as having been shown for the first time. It is a low-growing Primulaceous plant, with tufted leaves and lilac flowers, like those of an Androsace, but larger, and with the tube of the corolla longer than the calyx, and with only two seeds to the capsule. The species are the natives of North-Western America, the firs known species having been collected by Douglas not far from the sources of the Columbia River, and named in his honour by Dr. Lindley.

Araucaria imbricata Timber.-Mr. Ford, gr., Leonardslee, exhibited slabs of wood cut from a tree of this species, and which at 6 feet from the ground girthed 26 inches, the tree being 35 feet in height. The wood was yellow, soft, evenly grained, and, judging by the distance between the rings, quickly grown.

Numerous other plants and objects of interest were exhibited and commented on.

\section{SOCIETIES AND ACADEMIES.}

\section{LONDON.}

Royal Society, March 15.- "A Class of Functional Invariants." By Mr. A. R. Forsyth, F.R.S.

The memoir is occupied with the investigation of a class of functional invariants, constituted by combinations of the partial differential coefficients of a dependent variable, $z$, with regard to two independent variables, $x$ and $y$. The definition of the invariant is given by the property that, when the independent variables are transformed to $\mathrm{X}$ and $\mathrm{Y}$, and the same combina. 